\title{
Improving professional competence of the staff as a strategic factor for sustainable development of companies
}

\author{
Mihail Nikolaevich Dudin \\ Nataliya Vladimirovna Vysotskaya \\ Moscow Metropolitan Governance University, Russia \\ Evgenia Evgenevna Frolova \\ Alexander Askoldovich Pukhart \\ Peoples Friendship University of Russia, Russia \\ Marina Vladimirovna Galkina \\ Kutafin Moscow State Law University, Russia
}

Russian Presidential Academy of National Economy and Public Administration, Russia

\section{Keywords}

Staff development, staff development model, training center, evaluation of staff development

\begin{abstract}
The purpose of the present work is carrying out analysis of possibilities to improve the professional competence of personnel by implementing the most effective model of staff development. The urgency of the work is stipulated by the undeniable fact that one of the most important issues in the personnel management system is the development of professional competencies. This is confirmed by the experience of leading companies in advanced countries, whose success is achieved primarily due to the creation of highly effective personnel management mechanisms, which are based on an integrated approach to the use and development of labor potential.

Research methodology is based on the case-studies method oriented to the study of several models of personnel development of the companies involved in the study to compare their efficiency. This article describes the main theoretical and methodological aspects of people strategy development (staff development strategies) considering peculiarities and specificity of the socio-economic development of Russia. The article summarizes the key problems of people strategy development, which contribute to raising the level of professional competence of staff in the Russian business entities. The following conclusions were drawn based on research matter of the present article:

- based on the analysis and empirical comparison of Russian and foreign approaches (case studies of Lundbeck, Nordea Bank, Media Market, and LANIT companies) to the staff development, basic strategic models that can be used to enhance the level of professional competence of employees of the Russian business entities have been structured;

- it has been revealed that the most advanced systems of staff development aimed at enhancing the professional competence of the staff do not always have complex structure, at that more advanced staff development systems are adaptive and proactive (i.e. are focused on the development of competencies that will be needed not only in the present but in the future);

- main recommendations for improving approaches to staff development of Russian business entities have been proposed considering the best foreign practices (best practices of leading European companies), as well as considering features of socio-economic development of Russia in the current transition period.

The practical significance of the obtained results consists in the possibility of their use for the development of contemporary practice-oriented solutions related to the improvement of the personnel potential of Russian companies.

Corresponding author: Mihail Nikolaevich Dudin

Email address for corresponding author: dudin.n.mihail@mail.ru

First submission received: 15th April 2017

Revised submission received: 26th May 2017
\end{abstract}

Accepted: 30th June 2017 


\section{Introduction}

Human resources (HR) policy in contemporary conditions is one of the most important tools for managing business entity. Against the backdrop of globalization of economic relations, Russian business entities and companies must adapt their focus area and technology in HR management according to the world trends in this field to create a competitive environment in the HR management and a positive image of the employer.

\section{Literature review.}

The results of current research (Robert L. Mathis, John H. Jackson, Sean R. Valentine. Joan E. Pynes) confirm that the practical development of employees lacks strategic orientation, i.e. orientation towards the development prospects of business entities. This is largely due to significant differences in understanding of staff development.

Thus, Farooq Soofi (2015) tends to think that the staff development is the function and sphere of a human resource management, Tracey Tokuhama-Espinosa (2015) argues that it is a certain process. Lorraine R. Gay, Geoffrey E. Mills, Peter W. Airasian believe that staff development is primarily a complex aggregate of organizational measures aimed at staff training, requalification, and retraining (Gay et al., 2008). Seema Sanghi (2016) believes that these measures include also professional adaptation of staff, evaluation of candidates for vacant positions, planning working life and professional advancement of staff, and their periodic certification. Renate Wesselink, Vincent Blok, Sebastiaan van Leur, Thomas Lans, Domenico Dentoni understand staff development as "systematically organized process of continuous professional training of employees to perform new production functions, professional and qualification promotion, formation of top managers reserve, and improvement of social structure of the staff" (Wesselink et al., 2015). This approach to understanding the staff development is appropriate since it defines its place and value for each employee, as well as business entity in general. Thus, we can agree with the definition that staff development is integrated systematically organized continuous process of progressive qualitative changes in the professional qualification level of staff to ensure the achievement of strategic objectives of business entity through effective use of labor potential of each employee (Osagie et al., 2016; Dudin et al., 2017).

Comprehension of the objective need in staff development requires the allocation of major benefits for both the employee and the company in general, resulting from the effective implementation of this process. Such benefits may include increased value of highly qualified professionals, secure employment, formation and implementation of a rising career, high adaptability and maximum training of staff to address long-range objectives, motivation and job satisfaction, the possibility of identifying promising employees and managers, creating qualified and effective personnel reserve, the use of advanced technologies, and significant improvement of the quality of goods and services (Dudin et al., 2017).

\section{Research methodology.}

The research was carried out based on case-studies focused on the study of several models of personnel development in companies involved in the study to compare their efficiency. The method is based, firstly, on the highlighting of a unique component of the model, and, secondly, on comparison of these models in terms of two key indicators reflecting the effectiveness of efforts directed to staff development across the whole business structure.

All considered training and development models are multidimensional and somewhat similar, though each model of a specific business entity has its own unique components that are manifested more strongly than in other models.

Evaluation of the effectiveness of the staff development model was conducted based on two key indicators reflecting the effectiveness of staff development across the whole business entity:

- the indicator, which should be reduced, is the ratio of staff number to revenue (turnover, sales) of the business entity (for the Bank this is the operating revenue); 
- the indicator, which should be grown, is the ratio of business entity revenue (turnover or sales; or operating revenue for the bank) to staff number.

\section{Research results.}

This section summarizes the following case studies of staff development in leading European and Russian companies:

1. a systematic approach to the development of the "Lundbeck" training center (Annual Report 2015 for H. Lundbeck; Annual Report 2016 for H. Lundbeck);

2. corporate coach institute at the Nordea University (Annual Report 2016 Nordea Bank);

3. the simplicity of the Media Market model (Annual Report 2015/16, consolidated financial statements of METRO AG);

4. integration of internal and external training at the "LANIT" company (LANIT Group of Companies).

Thus, the first case study is a systematic approach to the development of the training center at "Lundbeck" company. The "H. Lundbeck A/S" is a Danish international pharmaceutical company.

Staff evaluation, training and motivation system at Lundbeck Corporation (in-grade positions of training and development) is systematically incorporated into the corporate business processes. An employee can develop in three lines of career, salary, knowledge and skills. When changing the execution functions of the employee, lines of action, or moving to another department or corporate business unit, the employee is evaluated in terms of his competencies (suitability for new position) and training (if necessary). Thus, the achievement of an appropriate qualification level makes no problems for both the employees and the company.

The training is organized in three areas: functional knowledge and skills (so called hard skills), managerial knowledge and skills (so called soft skills), and vocational skills (relevant to production). Training and development necessary to employee is recorded in individual development plans and formed prospectively, i.e. is determined for the future based on the evaluation of achievements and development. The only retrospective indicator is the lack of development of any two of the competencies during the year. In such cases, the company reviews the need for investment into the development of the employee and tries to determine the cause of the situation with his development.

Design of staff development system has begun with the construction of the staff evaluation system. The very definition of managers' evaluation mechanism (according to competencies) and evaluation of achievement of goals formed the basis for the design of the training and development system.

Main evaluation components, such as objectives and competencies formed the basis of the staff development system. The next step was the design of managers' development program. The concept of the university was developed after the first pilot projects. The very name "University" is not accidental. Lundbeck not only manufactures drugs, but also has its own research and development (R\&D) units involved in new products development, their marketing and sales. Such integrity requires the construction of training and development system, covering all corporate units and ensuring their harmonious combination.

The company developed common principles of the University, standards, and structure that are universal for the training of employees holding different positions in various fields. The standards and principles of the training and development system were implemented into the regulations: the appropriate objectives and procedures. Coordination of the staff adaptation process based on unified corporate standards is provided by the Training and Development Service.

The peculiarities of concerned model functioning:

1) Twice a year, Lundbeck Company holds managerial conferences and periodic briefings, presentations of Corporate University, where one of the points is the explanation of the staff training and development system operation, as well as changes that are being implemented, the need for 
systematic training and development, and how it helps to implement quality changes in the company.

2) After conducting staff evaluation and determining topics that the employee should study, the manager (or the employee himself) submits the application for appropriate training course. The peculiarity lies in the fact that the application notes not just the topic and the training objective, but describes what exactly is a production problem, or where the problem may arise, what goals will be achieved through training, specific skills that must be learned by the employee, what post-training activities will be organized by the employee for better absorption of new knowledge and implementing it in daily operations of the company (for example, presentation of innovations to colleagues, developing new documentation or prospective project business plan). On the one hand, such format of the application makes applicant to approach the training course responsibly, while on the other hand, it allows training and development service to better understand needs of training to ensure quality satisfaction of these needs.

The second case study is the corporate coach institute of Nordea University. Nordea Bank AB is a Swedish commercial bank, the international finance group, one of the largest in Northern Europe.

Today, the training and staff development issues at Nordea Bank are coordinated by Nordea University and training centers. Training centers are organized in each business unit of Nordea Bank. Linearly such training centers are subordinated to directors of the certain business areas and functionally should clarify programs and teaching methods with Nordea University.

Each training center is responsible for training of professional skills within the certain business area. Each training center has its own coaches, who are employees of the bank, who train junior staff. In turn, Nordea University is responsible for coordination of the work of training centers as well as training of middle-level and senior managers.

The cooperation method between business areas and Nordea University is quite interesting. Each business area pays Nordea University for training programs (training workshops and seminars), which are carried out by corporate training center. The cost of training is identified in internal rates, which may vary within different countries. There are basic mandatory programs that every employee must go through, and additional training, which is ordered by a certain business area at its discretion. Under such circumstances, the business unit is changing the motivation focus of attending the training provided by Nordea University, i.e. when paying for the group training, director of a business entity is interested in the high level of attendance of the training session.

One of the special requirements for Nordea Bank staff is that each head of department must be a coach (that is, be able to conduct at least 2 one-day training sessions per quarter; as a rule, one coach does not conduct more than 2 one-day training sessions per month; usually training sessions are held on Saturdays).

Coaches of training centers are exclusively employees of the Bank: in addition to heads of departments, the training sessions are conducted also by heads of subdivisions or leading specialists at their will. Coaches have access to training content, which was used earlier. They also develop authorial programs in accordance with the methodological cards that describe the basic training elements and material requirements. A mandatory requirement of each training session is the definition of three key insights/thoughts, which the listener will take from the training.

The coaches undergo special training and internal certification. Training of coaches is carried out twice a year. Each subsequent training session is the next step in improving the art of coaching. While at the start of establishing of training centers, Nordea University used to invite coaching company to conduct training for coaches, today all these trainings are conducted by their own efforts. Analysis of the training effectiveness is defined by:

- Participants' knowledge during the learning process, which is assessed through internal mandatory testing;

- Feedback forms after the training; 
- Internal e-forms for evaluation of the training, which are filled in by participants 3-7 days after the training, when they get rid of the emotional load.

The coach is certified by Nordea University, which is impartial, since the coaches do not report directly to Nordea University (it is worth mentioning that coaches work in the business units and report to their line managers; they are functionally linked to Nordea University through training centers of business units). During certification, which is conducted exactly during the training of coaches, the main attention is paid to:

- Knowledge of banking product;

- Presentation skills, especially the ability to hear the group.

Coaches conduct mini-training sessions in their groups, while representatives of Nordea University, who attend these mini-training sessions, give a professional evaluation of the coach. Similarly, to the organization of the training and staff development, the evaluation of the coach in Nordea Bank was modeled in such a way as to make its implementation as easy as possible. The fact that selling banking products always was the main strategy of the company, led to the development of a special rating system. Depending on the volume and type of sales, each employee was awarded bonuses. Ranking of employees is conducted in accordance with these bonuses. In Nordea Bank, it is established that if the employee is rated twice to $3 \%$ of the worst employees, then he is expected to be dismissed.

Obtained test results are used to:

- evaluate the performance of coaches, i.e., the higher scores of the trainees the higher the professional level of the coach;

- conduct a comprehensive evaluation of the employee; when taking the decision to move the employee to another position every manager receives the employee testing scores and information concerning the employee's ranking status.

Nordea University has defined the following performance indicators:

- Percentage of training programs fulfillment;

- Feedback evaluation forms.

The third case study reveals the simplicity of the Media Market model. Media Markt is a German chain of electronics stores and household appliances founded in 1979 and being part of the METRO GROUP.

European network of Media Markt has identified just one key competence and crystallized values that define the staff course of development. In addition to key competence, there is a list of management standards and product knowledge training. These three elements can describe the entire system.

Staff training and development model of Media Markt Company is coordinated by staff development service. The focus of the "sales" business model is clearly reflected in the staff training and development model, which includes:

- Technical education: the development and implementation of study guides for 40 major product groups, at that, guides are updated annually;

- Trainings conducted in three key areas: product knowledge, salesmanship, and development of managerial skills. Leading coaches, who develop training programs and deliver them to regional offices, are in the corporate head office. Coaches in the regions are best sellers, who have agreed to become corporate coaches and completed training program in the field of "the art of coaching";

- Seminars of manufacturers taking place centrally in the head office; more than 1,700 seminars are held annually.

- E-learning: leading coaches and experts develop special training manuals and prepare training material that every employee must learn to successfully perform their duties. Based on results of remote training, the employees pass exams (also remotely), affecting the results of their planned evaluation activities; 
- "mystery shopping" program is classically used to evaluate standards of customer service; the Media Markt company uses this tool for learning and development.

The learning model involves a series of trainings for different qualification levels in accordance with the competencies. It is worth noting that the skills that are defined for company employees as key competencies are fully correlated with the corporate values.

Store performance evaluation is always based on the level of sales. Staff performance evaluation, which subsequently influences future learning and development, is based on two indicators:

- Evaluation of the product knowledge level;

- Results of "mystery shopping" (the ability to sell/serve the customer)

The fourth case study concerns meeting the company and market needs: the integration of internal and external training of the "LANIT" company. "LANIT" (Laboratory of New Informational Technologies) is a Russian multidisciplinary group of IT companies.

The company annually hires about 140 selected employees, who undergo 3-month training. About $80-90 \%$ of those who took the courses get a job in a company.

After the employee was hired, he falls into the community of professionals named "competence group" according to his functional area. Each competence group coordinates their professional training area: exchanging knowledge and experience, supporting and assisting in problem solving, evaluating knowledge (testing). Each group includes 5 offices throughout a country. Competence groups carry on their activities through live meetings, videoconferencing, and intranet services.

In addition to learning the competences development, the head of division may request additional training for his subordinates in the "LANIT Networking Academy".

The structure of "LANIT Networking Academy" was formed in such a way as to achieve the main goals of the company, integrating the capabilities of external and internal training in various forms, as well as to provide a full cycle of training of employees at all levels. Full cycle of training includes:

- Confirmation of the training effectiveness level and professional knowledge and skills by passing exams in the certification center;

- Determination of the training format and conducting training; model).

-determination of training needs (by HR Department in accordance with the competence

Internal training and development includes:

- "LANIT Networking Academy", which produces more than 5,000 student-hours per year.

- Language School (300 students, 15 teachers); programs of "LANIT Networking Academy" and the Language School are licensed by the Department of Education and Science of the regional state administration. Tailored external programs for internal needs are developed and licensed by leading IT companies. Access and use of this software is possible due to the membership in the Microsoft IT Academy, Sun Academy, and Learning Solutions. Membership is provided within the unit of training center.

- "Cloud-based personal learning" is self-education and improvement through e-learning courses, on-line trainings, seminars, webinars, participation in conferences, and professional competitions;

- original courses of the "LANIT Networking Academy" center and partners such as Apple, Avaya, JAVA, Luxoft, Oracle, programming languages, information security, etc. (in total more than 25 items).

Curricula in the LANIT Company are made up based on staff evaluation, which includes:

- Performance evaluation (evaluation of core competencies and functional competences);

- Evaluation of the level of foreign language proficiency; 
- additional criterion (which is selected in accordance with the requirements of the employee's competence group and can consist of internal testing and passing certification exams in the IT field (VUE, KRYTERION) at external vendors, such as Adobe, Cisco, Citrix, HP, IBM, Juniper, Linux, Microsoft, Novell, SAP, VMWare, etc.

As a result, the employee gains a certain number of points for each training component. The topic and format of further training is determined in accordance with the number of points, lacking to move to the next career level. The evaluation results of the staff are used by "LANIT Networking Academy" to draw up a curriculum and form training groups.

\section{Discussion of the research outcomes.}

In accordance with the proposed methodology for evaluation of the staff development model performance, we identified key indicators reflecting the effectiveness of staff development. These are the ratio of staff number to company revenue (turnover or sales), and the ratio that is company's revenue (turnover or sales) in relation to the number of employees. Corresponding data are shown in Table. 1. Analysis findings have shown that the most effective is a model of staff training and development based on a system approach to the development of the training centre representing, according to the researchers, systematically organized (Wesselink, Blok, van Leur, Lans and Dentoni, 2015) and continuous integrated process (Osagie et al., 2016; Dudin, Ivashchenko, Frolova and Abashidze, 2017). In our opinion, the implementation of similar informative and training programs in Russian business entities is of great importance in modern strategic management of human resources.

Table 1. Performance indicators of different staff development models (Annual Report 2015 for H. Lundbeck; Annual Report 2016 for H. Lundbeck; Annual Report 2015 Nordea Bank; Annual Report 2016 Nordea Bank; Annual Report 2015/16, consolidated financial statements of METRO AG; LANIT Group of Companies)

\begin{tabular}{|c|c|c|c|c|c|c|}
\hline & \multicolumn{2}{|c|}{$\begin{array}{c}\text { Staff number, } \\
\text { thousand }\end{array}$} & $\begin{array}{c}\text { Revenue, mln } \\
\text { euro } \\
\text { (Danish Krone } \\
\text { for Lundbeck, } \\
\text { bln Rubles for } \\
\text { LANIT) }\end{array}$ & $\begin{array}{c}\text { change in ratio of staff } \\
\text { number to company } \\
\text { revenue (turnover or } \\
\text { sales), \% }\end{array}$ & $\begin{array}{c}\text { change in ratio } \\
\text { of company } \\
\text { revenue } \\
\text { (turnover or } \\
\text { sales) to staff } \\
\text { number, } \\
\%\end{array}$ \\
\cline { 2 - 6 } & 2015 & 2016 & 2015 & 2016 & & $+15.5 \%$ \\
\hline Lundbeck & 5.534 & 5.120 & 14594 & 15634 & $-15.5 \%$ & $+4.1 \%$ \\
\hline Nordea Bank & 29.826 & 30.596 & 15043 & 15792 & $-4.1 \%$ & $+8.2 \%$ \\
\hline Media Markt & 63.952 & 64.696 & 21327 & 21921 & $-8.2 \%$ & $+2.9 \%$ \\
\hline LANIT & 6.197 & 6.264 & 107.8 & 112.2 & $-2.9 \%$ & \\
\hline
\end{tabular}

When developing domestic models of staff development, it should be noted that according to researchers (Percy and Elliott, 2008; Clark et al., 2012; Osterwalder and Pigneur, 2010), the staff development process in business entity should be based on certain principles, such as the compliance between the nature of the staff training and development, and scientific and technological advancement forecasts, as well as the advancement needs of business entity; well-functioning feedback system between all levels of the business entity; the integrity of the entire development system and flexible use of various forms of staff development; the availability of financial and nonfinancial motivation of staff development; formation of staff development system taking into account the resource potential of business entity.

Employee management and development processes are interrelated and depend on the strategy of a business entity, and therefore need to be defined and executed as strategic processes.

The general strategy sets the priorities and develops the advancement areas of business entity for the future (Mintzberg et al., 2002; Stuart, 2000; Walliser, 2008), while the strategy in staff development, in turn, determines the level of professional qualification of the staff and the staff number required to provide an adequate level of effectiveness in achieving strategic goals. On a 
practical level, however, when determining the qualification level of employees in specific conditions, there might appear certain difficulties. It should be noted that the practical use of indicator such as the level of staff development necessitates the effective functioning of the strategic management system of business entity, because the correct definition of a set of indicators reflecting the development level of employees, and the generalizing analysis of these indicators allow upper management to coordinate the activity of business entity in the right direction, and plan appropriate measures to choose effective methods of their own employees development.

The level of staff development can be defined as a complex integrated indicator of the status of the employee's professional education, training and retraining process aimed at identifying changes in the professional qualification level of the staff to perform new production functions, form and plan succession pool, provide career advancement, and improve organizational culture of the staff that will allow implementing the strategic objectives of the business entity.

Comprehensive diagnostics of the staff development level and the status of implementation of this process should be accompanied by the development of appropriate evaluation tool, definition of the set of indicators characterizing the development of the employees of a business entity. This evaluation can be implemented in the framework of the staff management system on a step-by-step basis in the following sequence:

- Defining the study purposes and selecting staff development evaluation methods (needed for selection of the most significant indicators from the groups of labor efficiency of the staff, quality of staff management activities, and development expenses).

- Collecting statistical information and defining the expert group membership; creating source file (using fixation, survey, observation, and other methods).

- Processing collected information (evaluating each quality occurrence and determining the probabilistic level of manifestation of employee's qualities). Standardizing indicators, revealing the extent to which they effect on staff development, and selecting the most important quantitative indicators that will be included into the integral indicator of the staff development level.

- Conducting validity test of the obtained results.

- Defining the integral indicator of the staff development level.

- Analyzing obtained results and developing recommendations to improve the level of staff development of a business entity.

Apparently, the solution to the problem of evaluating the level of staff development is quite complicated, dynamic, and permanent. Therefore, company's management team must clearly remember that it is unacceptable not only ignoring the ongoing support of staff development, but also providing improper monitoring over the condition of this process and timely evaluation of results of the professional advancement of labor potential in employees at business entity.

\section{Conclusion.}

It follows from the foregoing that the conditions provided for professional advancement influence the effectiveness of staff development and return on invested financial resources and time. The staff development model should be based on individual approach to each employee, determination of the scope and nature of his activity, where the use of an employee brings the greatest effect, as well as results that give the opportunity to evaluate business capabilities of various specialists. This, in turn, will provide highly effective staff management policy.

The increase in business activity and labor productivity of employees, as well as preservation of competitiveness of business entity become possible only through the implementation and effective realization of the staff development process, which, for its part, requires significant investment. Investment into occupational development of the staff will not only increase the contribution of each employee in achieving the goals of the business entity and improve financial performance, but will 
also help creating a positive climate at the enterprise, raising the motivation of employees, their responsibilities, competence, and adhesion to the business entity.

In the framework of this article, within the scope of the current research, we have considered the general theoretical and methodological approaches to the design of staff development models at business entities to increase employees' competence level, as well as the fastest and most accurate achievement of the strategic goals of business entity. In further work, we intend to develop and complement the methodological approaches to the evaluation of professional competence of the staff, as well as present contemporary practice-oriented solutions related to the improvement of human resources of the Russian business entities in the context of current qualitative socio-economic transition.

\section{References}

Annual Report 2015 for H. Lundbeck A/S. Retrieved 11.03.2017 from

http:/ /investor.lundbeck.com/releasedetail.cfm?releaseid=954191

Annual Report 2016 for H. Lundbeck A/S. Retrieved 11.03.2017 from

http:/ / investor.lundbeck.com/releasedetail.cfm?ReleaseID=1010899

Annual Report 2015 Nordea Bank AB Group. Retrieved 11.03.2017 from

https:/ /www.nordea.com/Images/33-102773/2015-12-31_Annual-Report-2015-Nordea-BankAB_EN.pdf

Annual Report 2016 Nordea Bank AB Group. Retrieved 11.03.2017 from

https:/ / www.nordea.com/Images/33-69612/Annual\%20Report\%202016\%20Nordea\%

20Bank\%20AB.pdf

Annual Report 2015/16, consolidated financial statements of METRO AG. Retrieved 11.03.2017 from

http://reports.metrogroup.de/2015-2016/annual-report/servicepages/downloads/files

/entire_metrogroup_ar16.pdf

Clark, T., Osterwalder, A., and Pigneur, Y. (2012). Business models you: A one-page method for reinventing your career paperback. John Wiley and Sons, $264 \mathrm{p}$.

Dudin, M.N., Ivashchenko, N.P., Frolova, E.E., and Abashidze, A.H. (2017). Institucional'nyj podhod $\mathrm{k}$ formirovaniyu strukturnoj modeli razvitiya rossijskoj akademicheskoj sredy. European Journal of Contemporary Education, 6(1), pp. 22-38, (in Russ.) DOI:

10.13187/ejced.2017.1.22

Gay, L.R., Mills, G.E., and Airasian, P.W. (2008). Educational research: Competencies for analysis and applications. $9^{\text {th }}$ Edition. Prentice Hall, 648 p.

LANIT Group of Companies. Technical and strategic human resource management effectiveness as determinants of firm performance. A corporate website. Retrieved 11.03.2017 from

http://www.lanit.ru/

Mathis, R.L., Jackson, J.H., and Valentine, S.R. (2013). Human resource management. $14^{\text {th }}$ Edition. South-Western College Pub., 688 p.

Mintzberg, H., Lampel, J.B., Quinn, J.B., and Ghoshal S. (2002). The strategy process: concepts, context, cases. NY.

Osagie, E.R., Wesselink, R., Blok, Lans, V., and Mulder T.M. (2016). Individual competencies for corporate social responsibility: A literature and practice perspective. Journal of Business Ethics, 135(2), pp. 233-252.

Osterwalder, A., and Pigneur, Y. (2010). Business model generation: A handbook for visionaries, game changers, and challengers paperback. John Wiley and Sons, $288 \mathrm{p}$.

Percy, L., and Elliott, R. (2008). Strategic planning. Moscow, "Grebennikov" Publishing House, 416 p.

Pynes, J.E. (2013). Human resources management for public and nonprofit organizations: A strategic approach. $4^{\text {th }}$ Edition. San Francisco, Jossey-Bass, $528 \mathrm{p}$.

Sanghi, S. (2016). The handbook of competency mapping: Understanding, designing and implementing competency models in organizations. SAGE Publications India, 368 p. 
Stuart, T.E. (2000). Interorganizational alliances and the performance of firms: A study of growth and innovation rates in a high-technology industry. Strategic Management Journal, 21(8), pp. 799811.

Soofi, F. (2015), Human resource management: An introduction to human resource concepts, covering the key areas of performance reviews, discipline and termination as well as related concepts of absenteeism and diversity. Amazon Digital Services LLC, $55 \mathrm{p}$.

Tokuhama-Espinosa, T. (2015). The new science of teaching and learning: Using the best of mind, brain, and education science in the classroom. Teachers College Press, $256 \mathrm{p}$.

Walliser, B. (2008). Cognitive economics. Springer-Verlag. Berlin-Heidelberg, 185p.

Wesselink, R., Blok, V., van Leur, S., Lans, T., and Dentoni, D. (2015). Individual competencies for managers engaged in corporate sustainable management practices. Journal of Cleaner Production, 106(1), pp. 497-506. 